\title{
Disease Resistance of 'MP-29', a Clonal Interspecific Hybrid Rootstock for Peach, in Post-release Trials
}

\author{
Thomas G. Beckman ${ }^{1,6}$ \\ U.S. Department of Agriculture, Agricultural Research Service, Southeastern \\ Fruit and Tree Nut Research Laboratory, Byron, GA 31008
}

Philip A. Rollins ${ }^{2}$

Cooperative Extension Service, Clemson University, Spartanburg, SC 29303

James Pitts ${ }^{3}$

Chilton Research and Extension Center, Auburn University, Clanton, AL 35045

\author{
Dario J. Chavez \\ Department of Horticulture, University of Georgia, Griffin Campus, Griffin, \\ GA 30223
}

\section{Jose X. Chaparro 5 \\ Horticultural Science Department, University of Florida, Gainesville, FL 32611}

Additional index words. Prunus persica, peach tree short life, Armillaria root rot, root-knot nematodes, Meloidogyne spp.

\begin{abstract}
The primary focus of the stone fruit rootstock program at Byron, GA, has been the development of disease-resistant rootstocks for peach (Prunus persica L. Batsch). Historically peach tree short life (PTSL), aka bacterial canker complex, and Armillaria root rot (ARR) have been the two most important causes of premature mortality of commercial peach trees in the southeastern United States. Guardian ${ }^{\circledR}$, a seedling peach rootstock, was cooperatively released in 1993 by the U.S. Department of Agriculture (USDA)-Agricultural Research Service (ARS) and Clemson University. It has since been widely adopted by the southeastern peach industry. As a result, trees losses to PTSL have declined sharply. However, Guardian, like most other peach seedling rootstocks, is susceptible to ARR. ARR has now moved to the forefront as the primary cause of premature peach tree death in the Southeast. In response to this threat, the USDA-ARS in cooperation with the University of Florida, released 'Sharpe', a plum hybrid rootstock in 2007. Despite its broad disease resistance, 'Sharpe' proved unsuited for widespread commercial utilization due to its relatively poor cropping performance. In 2011, 'MP29', a semidwarf, clonal, plum $\times$ peach hybrid, was released for commercial trial. 'MP29's broad disease and nematode resistance, in combination with its dwarfing ability and excellent productivity, offered great promise for use in this production area and in others suffering from similar issues. Since its release, testing of 'MP-29' has continued both in researcher and grower trials. To date, performance has exceeded all expectations.
\end{abstract}

After the release of Guardian ${ }^{\circledR}$ in 1993 (Okie et al., 1994a), the USDA-ARS peach rootstock breeding program at Byron, GA, shifted its emphasis to combining resistance to PTSL, ARR, and several species of rootknot nematodes into a single rootstock. To a large degree, this was driven by the recognition of Guardian ${ }^{\circledR}$ 's deficiencies, in particular

\footnotetext{
Received for publication 19 Sept. 2018. Accepted for publication 17 Dec. 2018.

${ }^{1}$ Research Horticulturist.

${ }^{2}$ Upstate Peach Extension Specialist.

${ }^{3}$ Farm Manager (retired).

${ }^{4}$ Assistant Professor.

${ }^{5}$ Associate Professor.

${ }^{6}$ Corresponding author. E-mail: tom.beckman@ars. usda.gov.
}

its susceptibility to ARR (Beckman et al., 1997). This deficiency now looms large. With the suppression of PTSL that Guardian ${ }^{\circledR}$ rootstock provided, ARR, formerly second in importance to PTSL, has moved to the forefront and is now the single most important cause of premature tree death in the southeastern U.S. peach industry (Miller, 1994). Unlike stone-fruit production areas in Europe and California where Armillaria mellea appears to be the predominant species encountered (Adaskaveg et al., 2008), in the southeastern United States, the principal species encountered appears to be $A$. tabescens and only occasionally $A$. mellea (T.G. Beckman, unpublished data; Rhoads, 1954; Savage et al., 1953; Schnabel et al., 2005). The search for a rootstock capable of dealing with all these soil-borne disease problems was pursued via the testing of a wide variety of plum and peach species and the creation and testing of plum, peach, and plum $\times$ peach interspecific hybrids.

Early work demonstrated that FLA 1-1, a putative native North American plum hybrid, had potential for use on PTSL- and ARRinfested sites. FLA 1-1 was subsequently named and cooperatively released for trial by the USDA-ARS and the University of Florida as 'Sharpe' (Beckman et al., 2008). Unfortunately, ongoing testing subsequently demonstrated that 'Sharpe' was unable to match the production efficiency and fruit size offered by Guardian $^{\circledR}$ rootstock such that widespread commercial use could not be recommended (Beckman and Chaparro, 2015).

More recently, 'MP-29', a clonal plum $\times$ peach interspecific hybrid, was cooperatively released for trial by the USDA-ARS and the University of Florida (Beckman et al., 2012). 'MP-29' improved considerably on 'Sharpe' rootstock by offering not only PTSL resistance, comparable to Guardian ${ }^{\circledR}$, but also resistance to ARR, significantly better than that provided by Guardian ${ }^{\circledR}$ or even 'Sharpe' (Beckman et al., 2012). Additionally, 'MP29' offered resistance to several root-knot nematode species of interest in the Southeast, i.e., Meloidogyne incognita and M. floridensis. Horticulturally, 'MP-29' also offered a significant reduction in tree vigor, similar to that of 'Sharpe'. However, unlike 'Sharpe', 'MP-29' displayed excellent productivity and fruit size comparable to, if not better than, that provided by Guardian ${ }^{\circledR}$ rootstock (Beckman et al., 2012). Since its release, 'MP-29' has moved into commercial production and is now being offered by several nurseries in Tennessee, Florida, and California. The testing of the disease resistance and other attributes of 'MP-29' has continued in researcher and grower trials. The purpose of this report is to describe the disease resistance of 'MP-29' in these trials.

\section{Materials and Methods}

Experimental rootstocks were propagated either as seedlings or clonally as appropriate. Methodology has been previously published for PTSL (Okie et al., 1994b) and ARR (Beckman, 2011; Beckman and Pusey, 2001) trials. With one exception, Guardian ${ }^{\circledR}$ peach seedling rootstock was used as a standard for comparison in all PTSL and ARR trials. All trees were grown in a fumigated nursery (448 $\mathrm{kg} \cdot \mathrm{ha}^{-1}$ of $80: 20$ methyl bromide:chloropicrin under tarp) and June budded with a virus indexed scion variety. Finished trees were transplanted to field plots and planted according to the appropriate protocol (trial specific details follow). All trials were planted on sites with a known history of one or both diseases. No preplant fumigation was performed on any of the test sites so as not to reduce Armillaria inoculum or ring nematode populations present. Trees were managed per commercial recommendations (except in the 2000 and 2013 Byron 
trials in which trees were not dormant pruned but instead hedge pruned once a year in midsummer to remove approximately onehalf of the current season's growth). No supplemental irrigation was provided in any trials. Once each year, dead trees were inspected and cause of death determined.

Percent mortality was calculated for each ARR/PTSL plot and transformed as arcsine (square root) before analysis (Gomez and Gomez, 1984), with untransformed means presented. Data were analyzed by general linear models program of the Statistical Analysis System for personal computers (SAS Institute, 2010).

2007 Fort Valley, GA-ARR/PTSL Trial. Site had a history of both PTSL and especially ARR. Soil type was a Lucy sand. All trees were budded to 'Majestic' peach. Rootstock treatments included Guardian ${ }^{\circledR}$, 'Sharpe', and 'MP-29'. Trees were planted $4.9 \mathrm{~m}$ apart in row and $6.1 \mathrm{~m}$ between rows. Trees were aligned precisely over the previous planting plan so as to maximize exposure to ARR inoculum that remained in the soil after removal of dead trees. Design was a randomized complete block (RCB) with 10 replications of five tree plots (i.e., 50 trees total of each scion/rootstock combination), except for 'Sharpe' rootstock with only eight replications (i.e., 40 trees total).

2009 Landrum, SC-ARR/PTSL Trial. Site had a history of ARR and, to a lesser extent, PTSL. Soil type was a Brevard fine sandy loam. All trees were budded to 'Faye Elberta' peach. Rootstock treatments included Guardian ${ }^{\circledR}$, 'Sharpe', and 'MP-29'. Trees were planted $\approx 4.9 \mathrm{~m}$ apart in row and $6.1 \mathrm{~m}$ between rows. Rows were aligned over previous planting's rows to maximize exposure to ARR inoculum that remained in soil after removal of dead trees. Design was a RCB with 10 replications of five tree plots (i.e., 50 trees total of each scion/rootstock combination), except for 'MP-29' with only four replications (i.e., 20 trees total).

2012 Clanton, $A L-A R R$ Trial. Site had a history of ARR. Soil type was a Ruston fine sandy loam. All trees were budded to 'Julyprince' peach. Rootstock treatments included Guardian ${ }^{\circledR}$ and 'MP-29'. Trees were planted $3.7 \mathrm{~m}$ apart in row and $6.1 \mathrm{~m}$ between rows. Design was a RCB with eight replications of five tree plots (i.e., 40 trees total of each scion/ rootstock combination).

2013 Byron, GA-ARR (Waterlogging) Trial. Site had a history of severe ARR and had been in continuous use since the early 1990s for ARR screening. Soil type was a Norfolk loamy fine sand. All trees were unbudded. Trial treatments included peach seedling types, FL9-4 (an unreleased sister line to Flordaguard rootstock; Sherman et al., 1991), Flordaguard (clonally propagated rather than the typical seedling), and P-81 (a selection from an open pollinated population of Flordaguard), as well as clonal plum hybrids MH-1 (a putative $P$. angustifolia hybrid) and MH-101 (a complex plum hybrid selection). Trees were planted $0.6 \mathrm{~m}$ apart in row and $6.1 \mathrm{~m}$ between rows. Design was a
RCB with 10 replications of five tree plots (i.e., 50 trees total of each rootstock treatment). By this time, 'MP-29' had replaced Guardian ${ }^{\circledR}$ as the standard for comparison (resistant check) in ARR trials. Trial was established as a routine ARR trial, which included the enhancement of natural inoculum by placing an Armillaria-infested acorn near the crown of each tree shortly after establishment as previously described (Beckman and Pusey, 2001). However, a historically wet year after establishment resulted in serial ponding thereby providing an unplanned test of the waterlogging tolerance of trial materials.

2000 Byron, GA-ARR/PTSL Trial. Site had a history of both ARR and PTSL. Soil type was a Faceville fine sandy loam. All trees were budded to 'Redhaven' peach. Rootstock treatments included Guardian ${ }^{\circledR}$, 'Sharpe', and 'MP-29'. Trees were planted $\approx 0.6 \mathrm{~m}$ apart in rows $6.1 \mathrm{~m}$ apart. Design was a randomized complete block (RCB) with 10 replications of 5 tree plots, i.e., 50 trees total of each scion/rootstock combination.

\section{Results and Discussion}

2007 Fort Valley, GA-ARR/PTSL Trial. After only 5 years, losses to Armillaria on Guardian $^{\circledR}$ were so severe that the planting was removed (Table 1). In contrast, no trees on 'MP-29' had succumbed to Armillaria at that time. 'Sharpe' suffered intermediate losses to Armillaria, which is in agreement with previous work (Beckman et al., 2012). Neither 'MP-29' nor Guardian ${ }^{\circledR}$ suffered any losses to PTSL which is not surprising (Beckman et al., 2012; Okie et al., 1994a). However, losses on 'Sharpe' to PTSL were atypical because its resistance in previous work has been shown to be similar to Guardian ${ }^{\circledR}$
(Beckman et al., 2008). On closer inspection, it was discovered that a number of trees on 'Sharpe' had been set with the graft union slightly below the soil line, resulting in scion rooting. In a previous PTSL trial, which included a number of peach scion cultivars on their own roots, all of the scion cultivars proved to be highly susceptible to PTSL (Okie et al. 1994b). Hence, the PTSL susceptibility of the scion rooted trees of 'Majestic' that was observed in this trial is not surprising.

This experience pointed out the importance of planting depth when setting trees on size-controlling or disease-resistant rootstocks. Peach scions are typically high vigor on their own roots and generally provide little if any useful resistance to diseases of interest. Indeed, in this trial what initially drew our attention to trees on 'Sharpe' was the unusually high vigor a number of trees were displaying (data not shown); i.e., they were displaying the vigor of a typical peach seedling stock and not the vigor control that 'Sharpe' typically exhibits. These atypically high vigor trees on 'Sharpe' invariably proved to be scion rooted.

2009 Landrum, SC-ARR/PTSL Trial. Losses in this trial developed much more slowly than in the 2007 Fort Valley trial. Nonetheless, after 7 years, 'MP-29' had suffered significantly lower losses to ARR than had Guardian ${ }^{\circledR}$, as shown in Table 2. 'Sharpe' again was intermediate in this regard.

There were no significant differences in losses to PTSL, although the losses on 'MP29' deserve some additional comment. There were only four replications of 'MP-29' in this trial. Thus, the losses shown represent only three trees. This site was at significant elevation $(350 \mathrm{~m})$ for a peach site and suffered a

Table 1. Rootstock influence on cumulative mortality due to Armillaria (ARR), peach tree short life

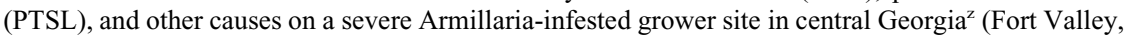
2007-11).

\begin{tabular}{lcccr}
\hline & & \multicolumn{3}{c}{ Cause of Death } \\
\cline { 2 - 4 } Rootstock & Alive (\%) & ARR (\%) & PTSL (\%) & Other (\%) \\
\hline 'MP-29' & $92 \mathrm{a}^{\mathrm{y}}$ & $0 \mathrm{c}$ & $0 \mathrm{~b}$ & 8 \\
'Sharpe' & $40 \mathrm{~b}$ & $17 \mathrm{~b}$ & $30 \mathrm{a}$ & 13 \\
Guardian $^{\circledR \mathrm{x}}$ & $42 \mathrm{~b}$ & $48 \mathrm{a}$ & $0 \mathrm{~b}$ & 10 \\
\hline
\end{tabular}

${ }^{\mathrm{z}}$ Established Spring 2007 with 10 replications of five tree plots in a randomized complete block design, budded with 'Majestic' peach.

${ }^{\mathrm{y}}$ Mean separation within columns via Waller-Duncan test, $\mathrm{K}$ ratio $=100$.

${ }^{\mathrm{x}}$ Guardian peach seedling rootstock was collected from a single seed line, SC3-17-7, now the dominant component of the bulk seed mix sold commercially.

Table 2. Rootstock influence on cumulative mortality due to Armillaria (ARR), peach tree short life (PTSL), and other causes on a severe Armillaria-infested grower site in north-central South Carolina ${ }^{z}$ (Landrum, 2009-16)

\begin{tabular}{lcccr}
\hline & & \multicolumn{3}{c}{ Cause of death } \\
\cline { 2 - 5 } Rootstock & Alive (\%) & ARR (\%) & PTSL (\%) & Other (\%) \\
\hline 'MP-29' & $75 \mathrm{a}^{\mathrm{y}}$ & $0 \mathrm{~b}$ & 15 & $10 \mathrm{~b}$ \\
'Sharpe' & $28 \mathrm{~b}$ & $26 \mathrm{ab}$ & 0 & $46 \mathrm{a}$ \\
Guardian $^{\circledR \mathrm{x}}$ & $62 \mathrm{ab}$ & $34 \mathrm{a}$ & 0 & $4 \mathrm{~b}$ \\
\hline
\end{tabular}

${ }^{\mathrm{z}}$ Established Spring 2009 with 10 replications of five tree plots in a randomized complete block design, budded with 'Faye Elberta' peach.

${ }^{\mathrm{y}}$ Mean separation within columns via Waller-Duncan test, $\mathrm{K}$ ratio $=100$.

${ }^{\mathrm{x}}$ Guardian peach seedling rootstock was collected from a single seed line, SC3-17-7, now the dominant component of the bulk seed mix sold commercially. 
significant freeze event in Feb. 2014 that resulted in bark splitting in many trees in adjacent commercial peach blocks that had been planted on either Guardian ${ }^{\circledR}$ or Halford rootstock. Several trees on 'MP-29' in this trial also exhibited bark splitting on the southwest side of the trunk, and three ultimately succumbed. In our experience, PTSL in the southeast is almost always attributable to bacterial canker (Pseudomonas syringae). However, cold injury is also an accepted cause (Beckman and Nyczepir, 2005). Therefore, although these three trees presented what in our experience are somewhat rare symptoms they nevertheless qualify as PTSL-caused deaths.

Rootstocks differed in losses to other causes as well. In particular 'Sharpe' stood out in this regard with virtually all of its other losses displaying symptoms typical of prunus stem pitting; i.e., swelling at and above the graft union combined with pitting at the graft union. However, we were unable to determine whether Tomato ringspot virus was present in these trees.

2012 Clanton, AL-ARR Trial. After 6 years, trees on Guardian ${ }^{\circledR}$ had suffered significantly greater losses to Armillaria than those on 'MP-29' as shown in Table 3. Neither rootstock treatment displayed significant losses to any other cause. This trial is still in progress at this time.

2013 Byron, GA-ARR (Waterlogging) Trial. This trial was initiated as a routine Armillaria screen in the Byron rootstock program. However, record-setting rainfall received the year of establishment (Fig. 1) provided an unexpected test of the waterlogging tolerance of the materials trialed as shown in Table 4. Not surprisingly, the group of three peach rootstocks suffered significantly greater losses than did the plum hybrid test selections or the 'MP29' check included in this trial. Although this was in part due to ARR losses (which had afflicted only the peach lines at this point in the trial), most of the tree death appeared to be attributable to waterlogging. Many of the losses in the peach lines attributed to other causes might well have been waterlogging as well but were not clearly so because we had to rely on subjective visual evidence to diagnose these losses (i.e., extremely dark brown to black necrosis in root tissue). Nevertheless, the profound difference in overall survival would appear to attest to the waterlogging resistance of the plum lines and MP-29.

Two additional points need to be made regarding 'MP-29' and water relations. It has been our experience that 'MP-29' needs to be handled carefully at planting to avoid drying out. Our early trials sometimes suffered excessive establishment losses (in excess of $1 \%$ to $2 \%$, T.G. Beckman, personal observation) when trees were transported bare root to the field covered only with wet burlap or similar material. When we changed our handling methods and instead held trees in water-filled tubs during transplanting, first year tree losses on 'MP-29' dropped to negligible levels. This precaution may need to be extended to first year irrigation as well.
Although supplemental irrigation is now the norm in the southeastern industry (T.G. Beckman, personal observation), growers do not always install it until the first cropping year. In one grower block on 'MP-29' established in 2016, there was a 6-week period in June following establishment with no rain (or supplemental irrigation). In this instance, trees on 'MP-29' grew off poorly (T.G. Beckman and P.A. Rollins, personal observation). An adjacent block of trees on 'MP29' that had been established the year before and that received regular rains (but no supplemental irrigation) grew off well that year and through 2016, demonstrating that if established properly, 'MP-29' could handle drought.

2000 Byron, GA-ARR/PTSL Trial. The impact of ARR resistance on orchard life can perhaps best be assessed by evaluating trees propagated on Guardian ${ }^{\circledR}$, 'Sharpe', and
'MP-29'. Figure 2 shows the time course of mortality on a severe PTSL/ARR test site at the Byron location. Although this site was also a severe PTSL site, the vast majority of tree losses were attributable to Armillaria; therefore, losses to all causes have been combined. Mortality of trees on Guardian ${ }^{\circledR}$ to Armillaria commenced in the third season and accelerated rapidly. In contrast, both 'Sharpe' and 'MP-29' were much slower to succumb to Armillaria. The management decision to pull a block depends on many factors, but productivity per acre is a primary one, and growers have indicated that they routinely remove blocks once tree occupancy falls much below 50\%. Guardian ${ }^{\circledR}$ reached this threshold after only 5 growing seasons on this site. In contrast, 'Sharpe' did not fall below $50 \%$ until the ninth season, whereas 'MP-29' did not reach this threshold until the 11th season, providing

Table 3. Rootstock influence on cumulative mortality due to Armillaria (ARR), peach tree short life (PTSL) and other causes on a severe Armillaria-infested grower site in central Alabama ${ }^{\mathrm{z}}$ (Clanton, 2012-17).

\begin{tabular}{lcccc}
\hline & & \multicolumn{2}{c}{ Cause of death } \\
\cline { 2 - 5 } Rootstock & Alive (\%) & ARR (\%) & PTSL (\%) & Other (\%) \\
\hline 'MP-29' & $98 \mathrm{a}^{\mathrm{y}}$ & $0 \mathrm{~b}$ & 0 & 2 \\
Guardian $^{\circledR \mathrm{x}}$ & $72 \mathrm{~b}$ & $28 \mathrm{a}$ & 0 & 0 \\
\hline
\end{tabular}

${ }^{\mathrm{z}}$ Established Spring 2012 with eight replications of five tree plots in a randomized complete block design, budded with 'Julyprince' peach.

${ }^{\mathrm{y}}$ Mean separation within columns via least significant difference, $P \leq 0.05$.

${ }^{\mathrm{x}}$ Guardian peach seedling rootstock was collected from a single seed line, SC3-17-7, now the dominant component of the bulk seed mix sold commercially.

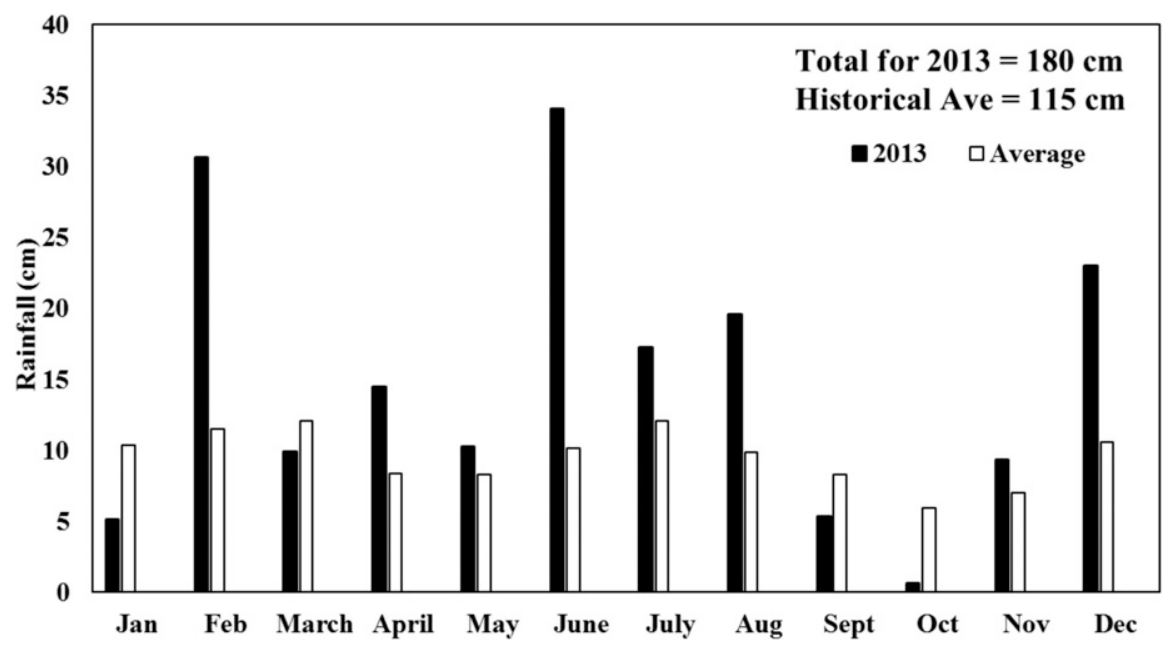

Fig. 1. Monthly rainfall $(\mathrm{cm})$ received at the Byron, GA, location in 2013.

Table 4. Rootstock influence on cumulative percent mortality due to Armillaria (ARR), waterlogging (WL), and other causes on a severe Armillaria-infested site in central Georgia ${ }^{\mathrm{z}}(2013-15)$.

\begin{tabular}{lcccr}
\hline & & \multicolumn{3}{c}{ Cause of death } \\
\cline { 2 - 5 } Rootstock & Alive & ARR & WL & Other \\
\hline 'MH-1' & $100 \mathrm{a}^{\mathrm{y}}$ & 0 & $0 \mathrm{~b}$ & $0 \mathrm{c}$ \\
'MP-29' & $97 \mathrm{a}$ & 0 & $0 \mathrm{~b}$ & $3 \mathrm{bc}$ \\
'MH-101' & $95 \mathrm{a}$ & 0 & $0 \mathrm{~b}$ & $5 \mathrm{bc}$ \\
P-81 (FG sel) & $26 \mathrm{~b}$ & 9 & $31 \mathrm{ab}$ & $34 \mathrm{ab}$ \\
FL9-4 & $20 \mathrm{~b}$ & 3 & $60 \mathrm{a}$ & $17 \mathrm{ab}$ \\
'FG-Clonal' & $12 \mathrm{~b}$ & 10 & $34 \mathrm{ab}$ & $44 \mathrm{a}$ \\
\hline
\end{tabular}

${ }^{\mathrm{z}}$ Established Spring 2013 with 10 replications of five tree plots in a randomized complete block design, unbudded.

${ }^{\mathrm{y}}$ Mean separation within columns via Waller-Duncan test, $\mathrm{K}$ ratio $=100$. 


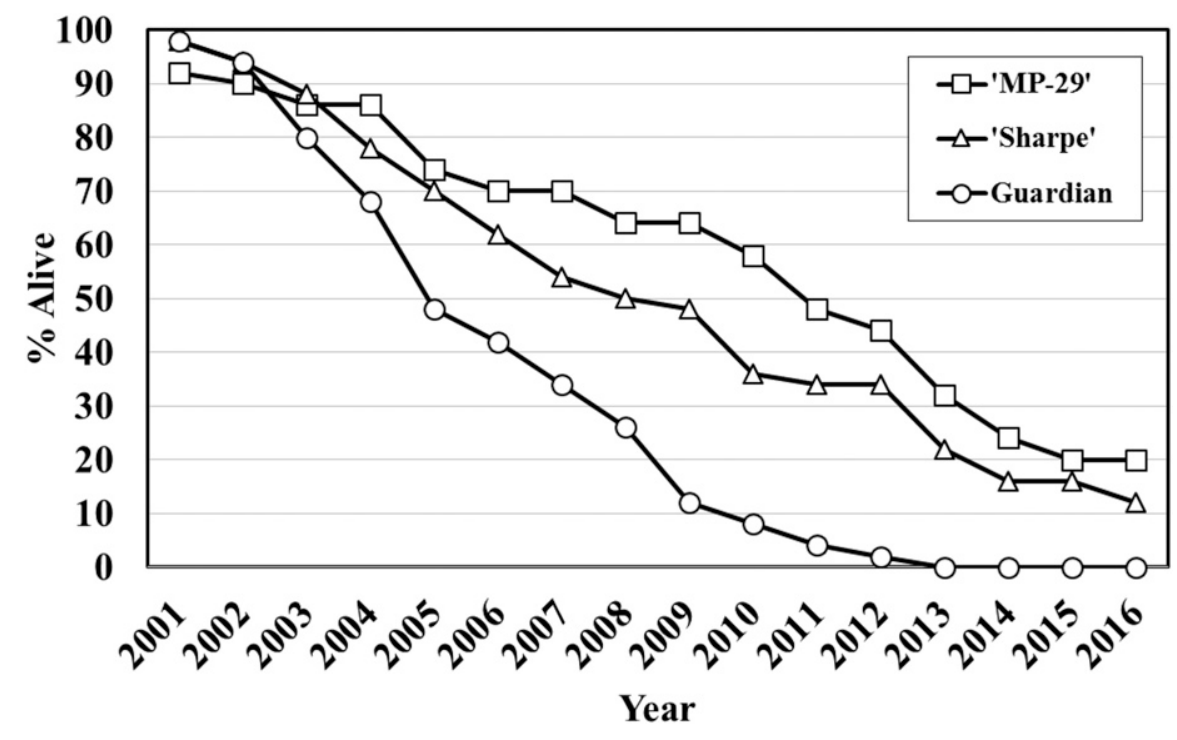

Fig. 2. Time course of tree mortality of 'Redhaven' peach budded on three rootstocks over 17 years on a severe ARR and PTSL site at the Byron location (2000-16).

essentially twice the useful orchard life as did Guardian ${ }^{\circledR}$.

\section{Conclusions}

'MP-29' was released in 2011 with high expectations for its future in the southeastern peach industry (Beckman et al., 2012). Now, 6 years post-release, the performance of 'MP29 ' has met the expectations presented in 2011. 'MP-29' has disease resistance, in particular to Armillaria root rot, that is second to none. It has resistance to all the important peach diseases endemic to the Southeast and would appear to be worthy of trial elsewhere, e.g., for bacterial canker and Armillaria worldwide. Rootstock development is continuing in the Byron program with new materials being screened each year. This is a slow and arduous process, for not only must the "ideal" rootstock provide exceptional disease resistance (PTSL, ARR, and root-knot nematodes), it must also display a host of other 'essential' horticultural qualities, such as ease of propagation, good
Handbook. G.E.S. Handbook No. 1, University of Georgia, Athens, GA.

Beckman, T.G. and J.X. Chaparro. 2015. Peach rootstock development for the southeastern United States. Acta Hort. 1084:171-178.

Beckman, T.G. and P.L. Pusey. 2001. Field testing peach rootstocks for resistance to Armillaria root rot. HortScience 36:101-103.

Beckman, T.G., J.X. Chaparro, and W.B. Sherman. 2012. MP-29, a clonal interspecific hybrid rootstock for peach. HortScience 47:128-131.

Beckman, T.G., J.X. Chaparro, and W.B. Sherman. 2008. 'Sharpe', a clonal plum rootstock for peach. HortScience 43:2236-2237.

Beckman, T.G., W.R. Okie, A.P. Nyczepir, G.L. Reighard, E.I. Zehr, and W.C. Newall. 1997. History, current status and future potential of Guardian $^{\mathrm{TM}}$ (BY520-9) peach rootstock. Acta Hort. 451:251-258.

Gomez, K.A. and A.A. Gomez. 1984. Statistical procedures for agricultural research. Wiley, New York, NY

Miller, R.W. 1994. Estimated peach tree losses 1980 to 1992 in South Carolina-Causes and economic impact, p. 121-127. In: A.P. Nyczepir, P.F. Bertrand, and T.G. Beckman (eds.). Proc. 6th Stone Fruit Decline Workshop, 26-28 October, 1992, Ft. Valley, GA.

Okie, W.R., T.G. Beckman, A.P. Nyczepir, G.L. Reighard, W.C. Newall, and E.I. Zehr. 1994a. Guardian (BY520-9), a peach rootstock for the southeastern United States that increases scion longevity. HortScience 29:705-706.

Okie, W.R., G.L. Reighard, T.G. Beckman, A.P. Nyczepir, C.C. Reilly, E.I. Zehr, W.C. Newall, Jr., and D.W. Cain. 1994b. Field screening prunus for longevity in the southeastern United States. HortScience 29:673-677.

Rhoads, A.S. 1954. Clitocybe root rot found widespread and destructive in Georgia and South Carolina peach orchards. Plant Dis. Rptr. 38:42-46.

SAS Institute, Inc. 2010. SAS for Windows, Version 9.3, SAS Institute, Inc., Cary, NC.

Adaskaveg, J.E., G. Schnabel, and H. Forster. 2008. Diseases of peach caused by fungi and fungal-like organisms: Biology, Epidemiology and Management, p. 352-406. In: D.R. Layne and D. Bassi (eds.). The Peach. Botany, Production and Uses. CAB International, Wallingford, UK.

Beckman, T.G. 2011. Progress in developing Armillaria resistant rootstocks for use with peach. Acta Hort. 903:215-220.

Beckman, T.G. and A.P. Nyczepir. 2005. Peach tree short life, p. 199-205. In: D. Horton and D. Johnson (eds.). Southeastern Peach Growers'
Savage, E.F., J.H. Weinberger, E.S. Luttrell, and A.S. Rhoads. 1953. Clitocybe root rot - a disease of economic importance in Georgia peach orchards. Plant Dis. Rptr. 37:269-270.

Schnabel, G., J.S. Ash, and P.K. Bryson. 2005. Identification and characterization of Armillaria tabescens from the southeastern United States. Mycol. Res. 109(11):1208-1222.

Sherman, W.B., P.M. Lyrene, and R.H. Sharpe. 1991. Flordaguard peach rootstock. HortScience 26:427-428. 